\title{
Sydney Lake: The historical park of KL
}

\author{
Nadiyanti Mat Nayan, Mohd Khedzir Khamis, \\ Siti Rasidah Md Sakip, Norhafizah Abdul Rahman \\ Faculty of Architecture, Planning and Surveying, \\ Universiti Teknologi MARA (Perak), 32610 Bandar Seri Iskandar, Perak, Malaysia \\ nadiy028@perak.uitm.edu.my
}

\begin{abstract}
In 1888, a first recreational area was created in Kuala Lumpur as a place for the British residents. Now, after more than 120 years this lake area still exists. Reintroducing the Sydney Lake Garden as the historical park is not about enhancing the colonial heritage but more on the history that this area once had. With the used of Greater Kuala Lumpur/Klang Valley (GKL/KV) as one of the main references, this paper will try to relate it on reviving this recreational area as one of new tourist attraction of Kuala Lumpur, the Sydney Lake Historical Park.

Keywords: Heritage Conservation; Historic Park; Heritage Place; Greater Kuala Lumpur/Klang Valley $(\mathrm{GKL} / \mathrm{KV})$

eISSN 2398-4279 @ 2018. The Authors. Published for AMER ABRA cE-Bs by e-International Publishing House, Ltd., UK. This is an open access article under the CC BY-NC-ND license (http://creativecommons.org/licenses/bync-nd/4.0/). Peer-review under responsibility of AMER (Association of Malaysian Environment-Behaviour Researchers), ABRA (Association of Behavioural Researchers on Asians) and CE-Bs (Centre for EnvironmentBehaviour Studies), Faculty of Architecture, Planning \& Surveying, Universiti Teknologi MARA, Malaysia.

DOI: https://doi.org/10.21834/ajqol.v3i10.111
\end{abstract}




\subsection{Introduction}

The purpose of this paper is to highlight the history of Sydney Lake and the ideas of enlivening it as the Historical Park of Kuala Lumpur. The discussion started with the history of the establishment of Sydney Lake in the 1880s and its functions during the early years of its creation. The second part of the paper will study the conditions of Sydney Park in the era of modernity, the 2000 s and the changes done ever since its existence. The last part of the paper will touch on the efforts taken by other conservation bodies especially in United States (National Park Service) and Great Britain (English Heritage). Sources from other international organizations such as United Nations Educational, Scientific, and Cultural Organization (UNESCO) and International Council on Monuments and Sites (ICOMOS) will also take into account in achieving the purpose of this research. Discussions continue with the actions taken by the Malaysian Government and the local authority in conserving the originality of Sydney Lake Garden. It will relate to the implementation of the Greater Kuala Lumpur/Klang Valley (GKL/KL) and others relevant laws implemented in Malaysia and its impact on this historic park.

\subsection{Literature Review}

\section{Sydney Lake: The Beginning}

The idea of the establishment of a recreational area in Kuala Lumpur started when Frank Athelstane Swettenham appointed as the Selangor Residents in 1882. During his early administration, he realized "the new capital city [Kuala Lumpur] was in urgent need of a facelift" (Sardar, 2000, p. 67). Swettenham's vision started with the refurbishment of the old town area. Sharing the same views was Alfred Reid Venning, the Selangor State Treasurer. However, A. R. Venning is more interested in creating a new recreational area for the Kuala Lumpur residents (Aziz, 2007). During the era, 'Padang' (Merdeka Square) was the only "main center of European communal activity" (Gullick, 1998, p. 50).

A suitable site identified at the edge of the city, near the 15th mile of the old Damansara Road. This area is consists of "a clear stream (Sungei Bras Bras) crossed the road after meandering through a valley that consisted of several acres of swamp" (Selangor Journal, II. p. 9, 22 September 1893, written by A. R. Venning) in (Gullick, 2007, p. 9). Filled with "briars and lalang, forest trees, screw pines and tree ferns" this area was "interspersed in picturesque confusion" (Gullick, 2007, p. 9). In 1888, the creation of a new lake garden began (Figure 1).

In 1889, the area which previously overgrown with wild bushes had changed to the "finest amenity" for the use of the people of Kuala Lumpur (Gullick, 1998, p. 24). On May 13, 1889, this Lake was formally open to the Kuala Lumpur's colonial elite by the Governor of the Straits Settlements, Sir Cecil Clementi Smith (Fatt, 2011, p. 165; The Kuala Lumpur Municipal Council, 1959, p. 17). Named after Mrs. Swettenham, Sydney, this area quickly became famous among the residents. This unique space that covered with greenery and flowering plants species is also enlivened with music played by the Police Band (Fatt, 2011, p. 165). 


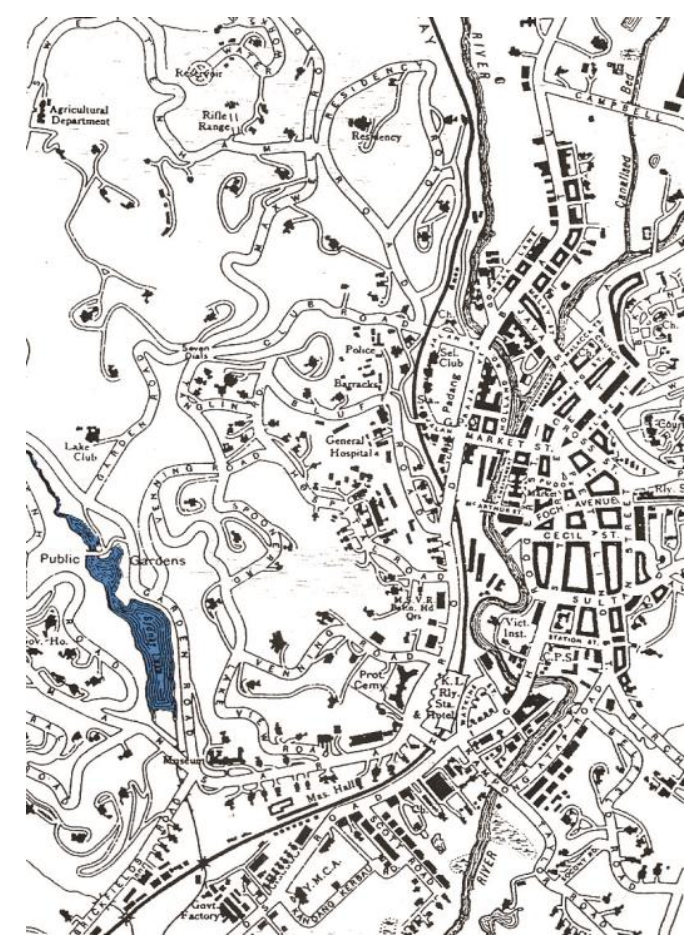

Figure 1: Map of Sydney Lake (highlighted in blue) and the old town of Kuala Lumpur in 1920 Source: (Adapted from Gullick, 2000, p. 231)

Started with 60 hectares, it has expanded to almost 70 hectares in ten years' time (Aziz, 2007). During the process "Europeans and some adventurous locals had explored the ravines to the north and west of the Lake Gardens" to find the most suitable area without losing the original functions and characters of the area (Fatt, 2011, p. 165). As reported by a British Residents at that time, Stanley Wilson Jones, in 1937:

"Quite a number of common lowland birds may be seen in the Lake Gardens. Black Panther, Golden Cats (Rimau Daun), Honey Bears and a small pack of wild dogs have been seen in these ravines following in the trail of their food supply which consists of monkeys, mouse deer, and small ground animals" (Fatt, 2011, p. 165).

\section{Its Early Functions}

During its early years, Sydney Lake has become a place for the elite to go for relaxing and strolling and "some even rode horses in the ravines" (Fatt, 2011, p. 165). One of the reports published by the National Achieves of Malaysia mentioned that Lake Garden could cater up to 20,000 visitors at a time (National Achieves of Malaysia, 1966). Series of the important 
events or functions held in Lake Garden summarized in Table 1.

Table 1: Important events and functions held at Sydney Lake Garden dated from 1903 to 1975.



Source: Adapted from National Archive Malaysia, 2015

The establishment of the Sydney Lake also acts as a center for new development in the nearby area. When Sydney Lake officially opened, roads were built, and so the buildings. In 1889, Residency Building (Carcosa Seri Negara) was purposely designed by overlooking the picturesque view of the Sydney Lake Garden (Gullick, 1998, p. 24). A year later, a new clubhouse, the Lake Club is built within the "luscious and green Lake Gardens" ("Royal Lake Club Kuala Lumpur," 2014). In 1928, one the famous Chinese Mansion owned by Chan Wing (now known as the former residence of the Yang di-Pertuan Agong) also built close to Sydney Lake (Figure 2). 


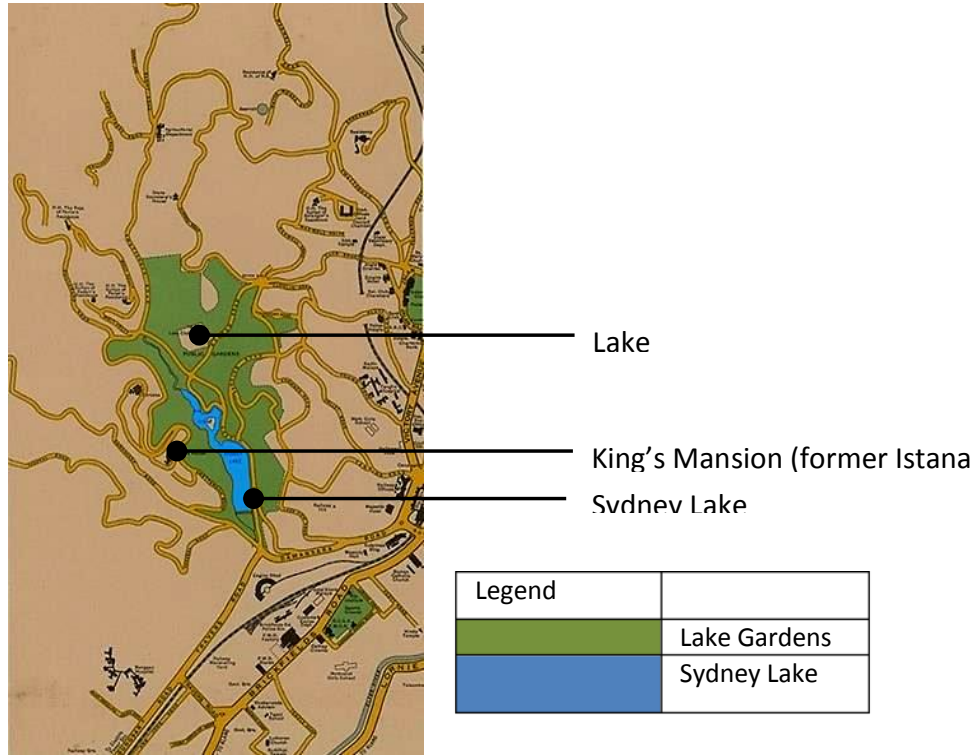

Figure 2: Map of Sydney Lake in 1950 with the adjacent area and buildings Source: (Adapted from National Achieves of Malaysia, 1950).

\section{Sydney Lake: Nowadays}

After more than 120 years, Sydney Lake is no longer an exclusive park to the British colonial's elite. Surrounded by high-rise building, this area manages to remain its greenery and survive with an area more than 100 hectares (Figure 3). Under the management of Kuala Lumpur City Hall (KLCH), it has evolved to cater the needs of the Kuala Lumpur's residents.



Figure 3: Sydney Lake Garden remains its identity even surrounded by new development Source: Author, 2015

In 2010, Sydney Lake Garden witnessed "the most extensive redevelopment project" 
(Kuala Lumpur City Hall, 2011). Thousands of new plants species planted in this historic garden. In 2011, this lake had once again rebranding and known as the Perdana Botanical Garden. Today's functions and characters of Sydney Lake is still in line with what has been proposed by A. R. Venning 120 years back (Fatt, 2011, p. 165).

\subsection{Methodology}

From the written resources, few elements in this area could consider as treasured heritage items. The Sydney Lake itself is one of the most valuable heritage items from the site. In fact, the creation of this area started with the lake. It has become the heart of the Lake Gardens and the center of enjoyment for the visitors (Gullick, 2000, p. 114). With its water fountains and bridges, it portrays the influence of nature and art in its design (Gullick, 2000, p. 113) (Figure 4). The Boat House also has its unique historical value. It has become the major meeting point during the reopening ceremony of Sydney Lake in 1975 (Figure 5). Although the existing building has rebuilt, it remains its site originality.

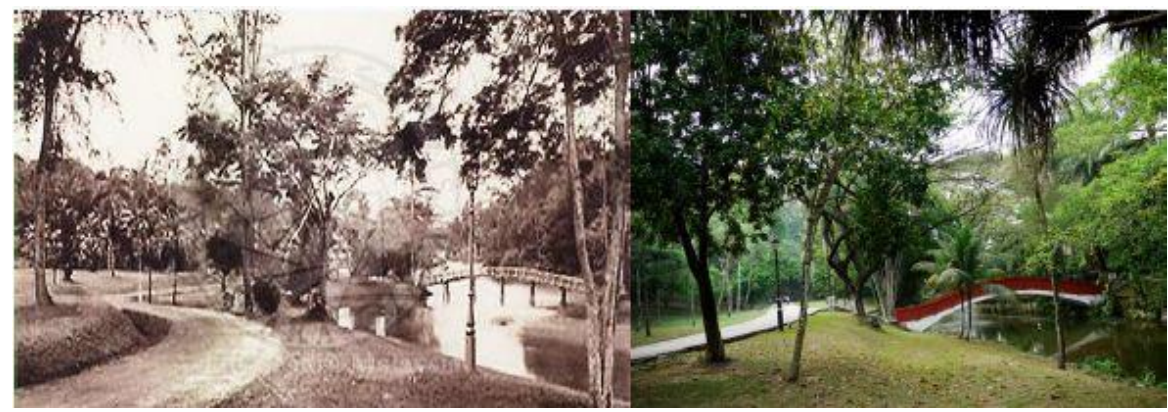

Figure 4: (a) One of the famous icon of Sydney Lake - the bridge (1910) and (b) The same picturesque view of the bridge in 2015 Source: (National Achieves of Malaysia, 1975); Author, 2015.

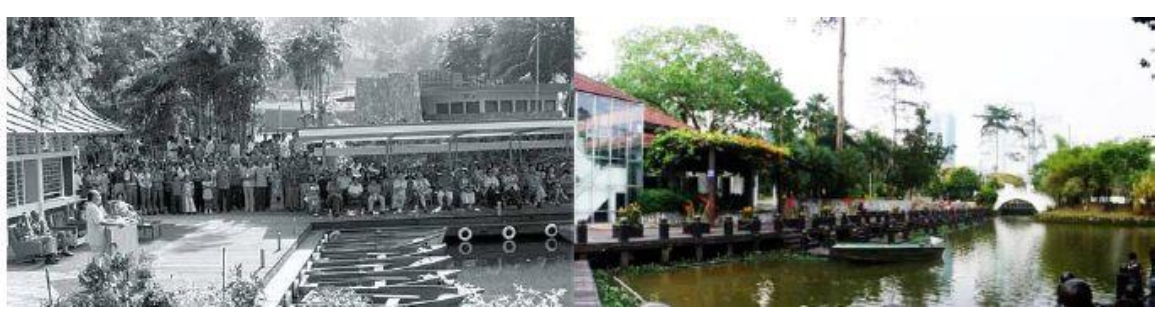

Figure 5: (a) The reopening ceremony of Sydney Lake (1975) and (b) The same area (Boat House) still exist until today

Source: (National Achieves of Malaysia, 1975); (Author, 2015).

However, site observation showed that there is no special plaque on site to commemorate the significant of Sydney Lake. There is only one plaque with the current Prime 
Minister's of Malaysia signature during the launched of Perdana Botanical Garden (Figure 6). The historical background of Sydney Lake could only access from the Kuala Lumpur Botanical Garden website. Therefore, the process of learning and understanding the history of the site is quite limited. The historic site plaque is important as it helps the public to appreciate this historic area and relate it to the actual site conditions.

\subsection{Findings and Discussions}

Referring to English Heritage (2014), parks or gardens with more than 30 years old deserves to Gazette as "historic" (English Heritage, 2014). However, looking at the age itself is not enough. In United States (US) for example, the recognition of National Historical Park (NHP) is placed under the management of National Park Service (NPS). Until March 2015, from more than 400 areas, more than 90 sites are listed under the Historic Park or Site categories (National Park Service, 2015). One of the well known NHP is the Mississippi's National River and Recreation Area (MNRRA), Minnesota. This river listed as NHP because of its "unique concentration of nationally significant resources" especially on historical and cultural aspects (National Park Service, 2015).

In Britain, the conservation effort for the heritage park is managed by English Heritage organization. Since 1983, the English Heritage "Register of Historic Parks and Gardens of special historic in England" has identifies more than 1,600 heritage sites (English Heritage, 2015).

Listed Historic Parks and Gardens categorized into three grades:

- Grade I - sites are of exceptional interest;

- Grade II $^{*}$ - sites are of particular importance, of more than special interest; and

- Grade II - sites are of special interest, warranting every effort to preserve them (English Heritage, 2015).

Based on this merit or band system, sites with most significant historical interest are eligible to register under the National Heritage List for England. The implementation of the value system is very useful in assisting parties involved especially the local planning authorities in the conservation works. Apart from efforts taken by the selected countries, there are also few examples of historic parks conservation involving the international bodies.

Based on listed garden under the UNESCO, most of these historical parks are nominated together with the heritage building. As for ICOMOS, preservation of historic gardens is mentioned in details in the Florence Charter 1982. Under this Charter, a historic garden is defined as "an architectural and horticultural composition of interest to the public from the historical point of view" (International Council on Monuments and Sites (ICOMOS), 1982, p. 1).

In 2011, this area was highlighted under the Entry Point Project (EPP) 7: Creating Iconic Places and Attractions. Under this EPP, a new initiative is known as the "Green Icon of Kuala Lumpur" is introduced (Performance Management \& Delivery Unit (PEMANDU), 2011). This 
"Green Icons" stated in the document is referring to the development of the Tun Abdul Razak Heritage Park. Sydney Lake is recognized as one of the gardens that included in the initiatives including six other adjacent gardens; the Orchid Garden, Deer Park, Bird Park, Butterfly Park, ASEAN Sculpture Garden and National Monument. Nine significant buildings are incorporated into the Tun Abdul Razak Heritage Park (Figure 7).



Figure 7: Tun Abdul Razak Heritage Park. Highlighted in blue is Sydney Lake area.

Source: (Adapted from Kuala Lumpur City Hall, 2011).

This area also stated in the Prime Minister's speech during the presentation of the Tenth Malaysia Plan 2011 - 2015. Under the Strategic Trust 5.1: Ensuring a Higher Quality of Life in Urban Areas, "the Government aims to provide an attractive and comfortable living environment for city dwellers to live, work and play. ... [including] the transformation of the Lake Gardens into a botanical garden" (Ministry of Housing and Local Government, 2011, p. 43).

The details of this positive initiatives included in this Plan in Chapter 6: Building an Environment that Enhances Quality of Life: Open Spaces and Green Corridors. The establishment of Tun Abdul Razak Heritage Park under the GKL/KV is a good start for Sydney Lake on recognizing it as a historical park. The efforts are taken by Kuala Lumpur City Hall also represented in its Structure Plan 2020. Under the Strategic Zone for City Centre: 17.2.3 (b): Green network and open spaces. The main attempt is to enhance this area as the "premier park of the City" (Performance Management \& Delivery Unit (PEMANDU), 2011). These actions portrait the Venning's vision in mid-1890 in transforming Lake Gardens as the "prime site" of Kuala Lumpur (Gullick, 2000, p. 166).

In 2012, Sydney Lake Garden designated as National Heritage under the natural site category. Under the National Heritage Act 2005 (Act 645), "natural heritage" is protected 
under Section 67: Declaration of National Heritage (Lembaga Penyelidikan Undang-undang, 2006, p. 133). Thus, any actions or decisions regarding this area need to consult for a particular permission from the Federal Government.

With these efforts given by the government and the local authorities involved, it is possible that one day Sydney Lake will be known as the Historical Park of Kuala Lumpur. However, more actions needed especially to publicize the history and origin of this area and its historical elements to the public. These steps need to be in line with rules and regulations stated and at the same time maintaining the originality of the site. At age 127 years old, Sydney Lake should be the pioneer project as the first historical park in Malaysia. It is not only witnessed in significant events happened in this area but most importantly, it is a place where the "positive cultural identity" is expressed from the various ethnic background of Malaysian (Bakar, 2002, p. 125).

\subsection{Conclusion}

As a conclusion, by gazetting this recreational park as one of the National Heritage, the area will be well protected from the future development. Hopefully, it would not face the same fate as what happen to Merdeka Parks in Kuala Lumpur and Melaka. For the sake of developments, both park already erased from the map and only remain in the historical text. Sydney Lake could become the 'living' reference to the future generations. There are lots of historical elements that still need to explore. The future research might include the landscape elements found in this area and how far its contributes to the history of Sydney Lake.

Today, the vision that was once had by Venning in 1890 to transformed Sydney Lake to a "place of healthful and relaxation for the public" has become reality (J.M Gullick, 2000). His ideas to ensure Sydney Lake Garden to become one of the well-known botanical garden and better than Penang or Singapore Botanical Gardens now achieved (Aziz, 2007).

\section{References}

Aziz, F. (2007). The road to paradise, The Star. Retrieved from http://www.thestar.com.my/Story/?file=/2007/9/29/central/18983744\&sec=central

Bakar, J. A. (2002). A design guide for public parks in Malaysia. Johor: Penerbit Universiti Teknologi Malaysia.

English Heritage. (2014). Historic parks and gardens in South Somerset, from https://www.southsomerset.gov.uk/planning-and-building-control/conservation/historic-heritageconservation/historic-parks-and-gardens/

English Heritage. (2015). How do parks and gardens become registered? Retrieved December 3, 2014, from https://www.english-heritage.org.uk/caring/listing/registered-parks-and-gardens/how-do-parks-and-gardensbecome-registered/

Economic Planning Unit. (2010). Tenth Malaysia Plan 2011-2015. Kuala Lumpur: Percetakan Nasional Malaysia Berhad. 
Fatt, L. S. (2011). Insider's Kuala Lumpur: Is no ordinary travel guide. Open your eyes to the soul of the city (3rd Edition ed.). Singapore: Marshall Cavendish Editions.

Gullick, J. M. (1998). Old Kuala Lumpur. Selangor, Malaysia: Penerbit Fajar Bakti Sdn. Bhd.

Gullick, J. M. (2000). A history of Kuala Lumpur 1857 - 1939. Kuala Lumpur: Malaysian Branch of the Royal Asiatic Society.

Gullick, J. M. (2007). Selections from the Selangor Journal. Selangor: The Malaysian Branch of the Royal Asiatic Society.

International Council on Monuments and Sites (ICOMOS). (1982). Historic Gardens (The Florence Charter 1981). Florence: ICOMOS.

Kuala Lumpur City Hall. (2011). Green icon of KL. Retrieved December 6, 2014, from http://www.greaterklkv.gov.my/iconicplaces/

The Kuala Lumpur Municipal Council. (1959). Centenary 1859 - 1959: Kuala Lumpur 100 years. Kuala Lumpur: The Kuala Lumpur Municipal Council.

Lembaga Penyelidikan Undang-undang. (2006). National Heritage Act 2005 (Act 645). Kuala Lumpur: International Law Book Services.

Ministry of Housing and Local Government. (2011). National Landscape Policy. Kuala Lumpur: Ministry of Housing and Local Government.

National Achieves of Malaysia. (1950). Map of Kuala Lumpur in 1950. Retrieved November 7, 2014, from http://ofa.arkib.gov.my/ofa/

National Achieves of Malaysia. (1966). Performances in conjuction with Yang di-Pertuan Agong's Birthday Retrieved December 14, 2014, from http://ofa.arkib.gov.my/

National Achieves of Malaysia. (1975). The opening ceremony of the Perdana Lake Garden Kuala Lumpur. December 12, 2014, from http://ofa.arkib.gov.my/ofa/

National Park Service. (2015). Find a park, March 5, 2015, from http://www.nps.gov/findapark/index.htm

Performance Management \& Delivery Unit (PEMANDU). (2011). Entry Point Projects. from http://app.kwpkb.gov.my/greaterklkv/entrypoint-project-iconic/

Royal Lake Club Kuala Lumpur. (2014). Retrieved November 11, 2014, from http://www.royallakeclub.org.my/

Sardar, Z. (2000). The consumption of Kuala Lumpur. London: Reaktion Books Ltd. 